\title{
DRAWING AN INFERENCE FROM THE FAILURE TO PRODUCE A KNOWLEDGEABLE WITNESS: EVIDENTIARY AND CONSTITUTIONAL CONSIDERATIONS
}

When a legal dispute is brought to court, the state has an unquestionable interest in encouraging the presentation of all relevant and material evidence in order to promote a fair adjudication. Certain categories of relevant evidence are excluded, however, because of possible untrustworthiness, social need for privileges of confidentiality, or improper state interference with an individual's constitutional rights. Beyond these important exceptions, evidentiary rules are premised on the proposition that the state has a right to every man's evidence.

When, therefore, during the course of a civil or criminal trial inaterial evidence known to exist is not presented, the court traditionally tries to attribute the failure to produce the evidence to the party who "naturally" would have produced it had it been favorable to his cause. ${ }^{1}$ The sanction imposed upon this party is the raising of an adverse inference froin his failure to act, ${ }^{2}$ and the inference may be argued to the jury by his opponent. ${ }^{3}$ While the inference rule logically applies to all failures of proof attributable to one party, it is precluded by the fifth amendment from operating in criminal cases when the missing evidence is the defendant's own testimony. ${ }^{4}$

Despite this limitation, the inference rule, particularly as it is applied to the failure to call a knowledgeable witness, is most unsatisfactory. It rests on a questionable psychological assertion and, as presently administered, leaves much rooin for inaccuracy in the inference permitted. Furthermore, the rule serves as a shield for constitutionally impermissible comment drawing attention to the silence of non-testifying criminal defendants. This Comment will explore the weaknesses of the inference rule generally and discuss means of minimizing inaccuracy in the inference drawn. It will further argue that all comment about a criminal defendant's failure to produce a witness should be prohibited as infringing upon his fifth annendment privilege against self-incrimination.

1. C. MCCORMICK, MCCORMICK'S HANDEOOK OF THE LAW OF EVIDENCB $\$ 272$, at 656-57 (2d ed. Cleary 1972) [hereinafter cited as MCCoRMaCK].

2. Id. at 656 .

3. Id. at 659 .

4. Griffin v. California, 380 U.S. 609 (1965). 


\section{INFERENCES TO Be DRAWN FROM A PARTY's FaILURE To Produce a KNowledgeable Witness}

\section{A. The Basis for the Traditional Inference Rule}

The failure to call a particular witness or voluntarily to produce documents or objects in one's possession is conduct evidence. ${ }^{5}$ The party's behavior is interpreted as an indication of knowledge that his opponent's evidence is true, or at least that the tenor of the evidence withheld would be unfavorable to his cause. ${ }^{6}$ The basis of the inference from conduct to fear of exposure is said to be "our experience of the operation of human nature." Courts traditionally have explained that the psychological basis for the rule is the instinct of selfpreservation: ${ }^{8}$ fear of criminal punishment and the disgrace of conviction, or deep anxiety over a threat to one's honor, would naturally compel a person to produce in court any favorable evidence he possessed. ${ }^{\circ}$

5. 2 J. WIGMORE, EVIDENCE $\$ 265$, at 87 (3d ed. 1940) [hereinafter cited as WIGMORE].

6. The exact nature of the inference causes some confusion. According to Wigmore, the general principle governing all conduct evidence is that "[w]e argue from an observed effect-conduct-to the probable cause-a specific mental state." 2 WIGMORE $\$ 265$, at 87 . Applied to the inference drawn when a party fails to call a witness, this principle suggests that the underlying state of mind is the party's fear of exposure. This fear, in turn, permits the inference that the missing evidence would be unfavorable to the party's cause. Id. $\S 285$, at 162 . McCormick, in discussing other types of admission by conduct, likewise mdicates that one infers from the relevant behavior a causal mental state. MCCORMICK $\$ 270$, at 652 (silence); $\$ 271$, at 655 (flight and similar acts). But when he discusses the inference from a failure to produce witnesses, he overlooks the intermediate step of inferring the party's state of mind, remarking only that "the inference arises that [the testimony] would have been unfavorable." Id. $\$ 272$, at 657 . One suspects that the inference operates this way in the minds of jurors, that they think not about the party's state of mind but directly about the content of the missing testimony. Further, jury instructions probably mention only the ultimate inference that the evidence would be unfavorable. However, this treatment of the operation of the inference is only a verbal shortcut: clearly the two stages of inference-from conduct to state of mind, and from state of mind to content of the evidence-are logically necessary. The inference rule only makes sense if it makes reference to a party's state of mind-if it assumes that the party made some reasoned decision about what evidence he would present in court. If what was or was not presented in court was completely fortuitous, omissious would be meaningless. Only the party's choice, based on his knowledge about the evidence, gives the omission of some evidence significance. Therefore, the precise approach of Wigmore is preferable for purposes of analysis, although the final result is the same uuder the shortcut language.

7. 2 WIGMORE $\$ 265$, at 87.

8. State v. Grebe, $17 \mathrm{Kan} .458,459-60$ (1877) (Brewer, J.), quoted in 2 WigMORE $\$ 285$, at $165-66$.

9. Attorney-General v. Pelletier, 240 Mass. $264,316,134$ N.E. 407,423 (1922) (Rugg, C.J.), quoted in 2 WIGMORE $\$ 289$, at 172 . 
In civil cases an identical inference arises from a party's failure to take the stand himself as from his failure to call other witnesses. ${ }^{10}$ Logically, the rule would have the same scope in criminal cases. However, the Supreme Court has held that comment on a criminal defendant's failure to testify derogates his privilege against self-incrimination. ${ }^{11}$ The fifth amendment carves out a sub-set of cases to which the rule permitting comment on the failure to produce evidence cannot apply: those criminal cases in which the missing evidence is the defendant's own testimony.

In ordinary cases not presenting the problem of constitutional privilege, courts determine whether the inference should be drawn by asking whether it would be "natural under the circumstances" for one party to produce the missing evidence if favorable to his cause. ${ }^{12}$ In administering this test, the courts have considered two general factors: whether the omitted evidence would be material and not merely cumulative, ${ }^{13}$ and whether the information is "peculiarly available" to one party. ${ }^{14}$ If the missing evidence is a document or other object, the availability test is easily met by the party's possession of or exclusive access to the tangible evidence..$^{15}$ Similarly, a knowledgeable witness may be available only to one party if that party alone knows the witness' identity or whereabouts. More frequently, however, the witness is known to both parties and is subject to subpoena by either; to determine "peculiar availability" in this situation, courts have considered whether the relationship between the witness and the party charged with nonproduction is sucl that one would ordinarily expect the witness to testify favorably to that party. ${ }^{16}$ In civil cases the courts generally have assigned the failure to produce only when one party and the witness share a formal relationship such as that between members of the same family, an employer and his employee, or an attorney and his chent. ${ }^{17}$ In criminal cases the analysis is usually less mechan-

10. 2 WIGMORE \& 289 , at 171 .

11. Griffin v. California, 380 U.S. 609 (1965).

12. MCCORMICK \& 272, at 656; 2 WIGMORE \& 286, at 166.

13. 2 WIGMORE $\$ 287$, at 168 ; MCCORMICK $\$ 272$, at 656 .

14. 2 WIGMORE $\$ 286$, at 166 .

15. The earliest application of the inference rule involved the withholding of tangible evidence. In the 1772 case of the Chimney-Sweeper's Jewel, a sweep found a jewel and left it with an appraiser who then refused to return it or to produce it at trial. The English court ruled that if the jewel was not produced, it would infer the highest possible value. 2 WIGMORE $\S 285$, at 166 . The rule was only later applied in the more difficult situation where a witness is not called by either party. With widespread use of pretrial discovery in civil cases, the inference rule will be invoked less and less in the classic "missing jewel" type of case. Tangible evidence will be "peculiarly available" to neither party because it is discoverable by either.

16. 2 WIGMORE $\& 287$, at 168 ; MCCORMICK $\& 272$, at 656-57.

17. See cases collected in Annot., 5 A.L.R.2d 893 (1949). 
ical: the focus is on whether the witness is likely to be known by the defendant to have information consistent with the theory of the defense. ${ }^{18}$

An inference will not be allowed if a party introduces evidence explaining the reasons for his conduct, and if the evidence is truly unavailable or shown to be immaterial. ${ }^{19}$ But if the inference is justified, counsel can discuss it in closing argument, and the party's failure to produce might be the basis for a jury instruction. ${ }^{20}$ While the inference cannot supply any missing element of proof of the prima

By eliminating some of the factors that make a witness peculiarly available to one side rather than the other, the increasing use of discovery in civil trials also diminishes the need and justification for the inference rule as applied to uncalled witnesses. MCCoRMick $\$ 272$, at 657 , and cases there cited. Through discovery, the identity and whereabouts of all potential witnesses should be known to both parties prior to trial; since the actual content of a witness' prospective testimony is known, there is no reason to rely on a supposition about "relationship" to determine who slould call a witness. Whoever will in fact benefit most from the prospective testimony can and should subpoena the witness: a party should not be entitled to rest on an inference based on his opponent's state of mind when he could easily and safely call the relevant wituess if the testimony would indeed be helpful. Accurate fact finding will certainly be aided by having a wituess' positive testimony on the record rather than relying on inferences based on speculation about unproduced testimony. But these remarks about discovery apply only to civil trials. The inference rule still applies full force to criminal trials, where limited one-way discovery is the rule.

It should also be noted that the inference rule is based on an assumption that a wituess typcially "belongs" to one side of a dispute. This assumption is related to the traditional notion that a party who calls a witness in effect vouches for his credibility and is therefore not permitted to impeach the witness. MCCoRMick $\S 38$, at 75. The trend in evidentiary rules today, however, is to permit a party to impeach all witnesses, including those he calls to the stand. See, e.g., Calr. Evid. Code $\S$ 785 (West 1966); Proposed Rules of Evidence for the United States Courts and Magistrates, Rule 607. The existence of a special relationship between a potential witness and one of the parties becomes procedurally less significant and further diminishes the need for the inference rule in civil cases.

18. See, e.g., United States v. Cox, 428 F.2d 683, 688 (7th Cir. 1970), cert. denied, 400 U.S. 881 (1970); Commonwealth v. Domanski, 332 Mass. 66, 70, 123 N.E.2d 368, 371 (1954).

The government's failure to produce a knowledgeable witness is similarly subject to comment by the defense. But seldom would an infereuce froin the witness' absence be favorable to the defendant where the witness is not one the defendant would be more likely than the state to call. One example of such a case, however, is State v. Clawans, 38 N.J. 162, 183 A.2d 77 (1962), in which the state failed to call a prison matron who had been sitting with the defendant at the time le was alleged to have suborned a third party with whom he spoke. The defendant was entitled to an instruction that the state's failure to call its employee raised in inference in the defendant's favor.

19. 2 WIGMORE $\S 290$, at 178 . Unavailability may be due tơ a witness' illness or absence from the jurisdiction, to the party's ignorance as to the wituess' whereabouts or the need of proving the facts in question, or to the witness' disqualification under a privilege. Id. § 286 , at 166 .

20. MCCORMICK $\S 272$, at 659 . McCormick notes, at 658 , that while some courts speak of a "presumption," the failure to produce properly raises only a permissible inference and is treated as such even by these courts. 
facie case, it affects the weight of the evidence on the disputed issue. ${ }^{21}$ Evidence presented by the invoking party will be more convincing, and the value of any evidence which his opponent produces will be impaired. As a practical matter, the trier of fact will probably treat the invoking party's evidence as undisputed.

\section{B. A Critical Look at the Inference Rule}

Courts have begun to apply the inference rule with respect to uncalled witnesses more cautiously in both civil and criminal cases. ${ }^{22}$ Unfortunately, these courts have not clearly explained the reasons underlying their mistrust of the rule. One obvious difficulty is the uncertain psychological foundation for the inference. Whether the instinct for self-preservation or the desire to defend his honor would necessarily cause a person to testify or present other evidence in his own behalf is certainly open to dispute. In many civil cases, for example, the traditional defense-of-honor motivation is weak or nonexistent. Honor is not at stake when two insurance companies litigate liability for an automobile accident, and a party is not dishonored when he is held strictly liable without proof of fault. Of course, the threat of a monetary sanction will induce parties to present convincing evi-

21. McCormick $\S 272$, at 658; 2 WIGMORE $\S 290$, at 179 . In People v. Rides, 273 N.Y. 214, 7 N.E.2d 105 (1937), a defendant in possession of alcohol manufactured without a license claimed it was for treatment of his mother's arthritis. He did not call his mother or her doctor as witnesses, but the inference from this failure could not take the place of affirmative proof that the alcohol was manufactured for sale.

22. MCCORMiCK $\S 272$, at 657. See, e.g., Jenkins v. Bierschenk, 333 F.2d 421 (8th Cir. 1964). In a suit arising out of an automobile accident, defendant presented evidence that a ball bearing had broken, and was acquitted. Defendant did not call as a witness his own son, who had been in a previous accident with defendant's car. Although the father-son relationship would traditionally support an adverse iuference for failure to call a material witness, the court held that no adverse infercnce was permissible because there was nothing which indicated that the son was not equally available as a witness to both parties. The court stated:

We adhere to our comment that any rule creating a presumption of this kind is to be applied with caution and we agree with the trial court that "there must be a reason for such a supposition, and a factnal area within which it may logically operate. The supposition must rise above the level of mere possibility. ...."

Id. at 425. In Wynn v. United States, 397 F.2d 621 (D.C. Cir. 1967), a criminal defendant testified to an alibi defense but produced no alibi witnesses. The prosecutor's comments on this omission and the court's broad instruction to the jury that it might infer that the testimony of a witness peculiarly available to but not called by a party would have been unfavorable to that party, were criticized by the appellate court, which on its own initiative raised the impropriety of the remarks for benefit of the lower court should there be a retrial. The court admonished:

On this record, one must speculate as to appellant's capability, and the more so as to one peculiar to him, to have brought forth any of the uncalled witnesses .....

Id. at 625 . Yet this is just the kind of speculation on which the inference is ordinarily based. 
dence, and in some cases financial considerations may be overwhelmingly important. But the threat of a money judgment hardly equals fear of imprisonment as a motivation to produce evidence, and certainly in many cases the motivation will be counterbalanced by valid reasons for not producing evidence.

A person's failure to produce evidence is ambiguous, ${ }^{23}$ a variety of considerations unrelated to guilt might motivate him not to put a particular witness on the stand. ${ }^{24}$ He may fear that the witness he calls will be impeached because of a criminal record, that the person's appearance or mannerisms will adversely impress the jury, or that the potential witness is just too unpredictable or untrustworthy to call. ${ }^{25}$ A party may not want to involve his family or associates in a sensational trial, to subject a potential witness to the stress of trial examination, or to produce a witness who may be forced on crossexamination to reveal personal facts embarrassing to the hitigant. In a "political" trial or investigation, a person may refuse to participate as a protest against the nature of the proceeding. Yet none of these reasons for nonproduction is sufficient to prevent the operation of the inference rule. If the knowledgeable witness is available, the inference can be argued.

The existence of these numerous considerations-based not on guilt but on tactical choices and personal sensibilities-must cast doubt

23. The Supreme Court in Griffin v. California, 380 U.S. 609 (1965), acknowledged the ambiguity of a defendant's failure to testify. It pointed out that his silence may be attributable not to consciousness of guilt, but rather to his fear of impeachment, doubts about his ability to hold up under the stress of questioning, or fear that his appearance or mannerisms would adversely affect the jurors and make them doubt eveu a true story. He might "prefer to rely on the presumption of innocence . . . ." Id. at 613, quoting Wilson v. United States, 149 U.S. 60, 66 (1893). See also E. GRISWOLd, THe FIFTH AMENDMENT TODAY 20 (1955).

While a person's out-of-court silence is sometimes treated as an admission by conduct and admitted as substantive evidence, the ambiguity of such conduct evidence has always been recognized. The rule permitting its use is carefully restricted by the requirements that an accusation be made in the party's presence, that he hear and understand it, and that the circumstances are such that he would normally be expected to deny the charge. MCCoRmICK $\$ 270$, at 651-52; 4 WIGMORE $\S 1071$, at 70. However, a crimmal defendant's silence even in the face of accusations is behavior protected by the fifth amendment and gives rise to no adverse inference once a proceeding reaches the accusatorial stage. Miranda v. Arizona, 384 U.S. 436 (1966).

24. Many of the reasons for not producing a witness do not apply to documents or other objects (e.g., doubts about mannerisms or predictability); and the test for "availability" justifying an inference from the failure to produce evidence is much more straightforward and easily applied to objects than to witnesses. See note 15 and accompanying text supra. Objections to the inference rule, therefore, have focused on its application to the failure to produce a knowledgeable witness, MCCoRMICK $\S 272$, at 656 , and the remainder of this Commeut will do likewise.

25. See note 23 supra. The reasons cited by Griffin for a defendant's decision not to take the stand personally apply equally to his decision not to put a particular witness on the stand. 
upon the validity of the simplistic psychological premise underlying the inference rule. The inferential leap from conduct to underlying state of mind leaves substantial room for inaccuracy. Furthermore, it should be remembered that the premise that the witness' testimony would be material is itself inferred from the circumstances of the case. Here, too, speculation may introduce inaccuracy in the final inference derived from the witness' absence.

McCormick suggests that the inference rule is disfavored because it invites waste of valuable court time. The possibility of comment on a failure to produce induces litigants to submit unnecessary evidence. $^{26}$ But frequently when the inference is invoked, too little time is expended to examine whether the inference is proper; and if the rule were more carefully administered, it might consume even more court time than it does now.

Normally, a judge decides the propriety of an adverse inference when an instruction thereon is requested at the close of all the evidence, or when counsel objects to an improper comment during closing argument. At that point, the court must determine the materiality and availability of the missing evidence from the existing record, although it is unlikely that any testimony will have been devoted to these issues. Under such conditions there is a high chance of error in evaluating the circumstances that allegedly give rise to the inference.

Recoguizing this problem, some courts recently have suggested that a judge should rule only after the parties create an explicit record of the circumstances surrounding the failure to produce. One court suggested that before the government can raise the inference against a criminal defendant, the record should show the extent of the party's knowledge of the whereabouts of the witness at the time of trial, whether the witness is within the court's jurisdiction, and whether the government had a chance to call the absent witness itself, either before or during trial. ${ }^{27}$ Another court declared that there should be an

26. MCCORMICK \& 272, at 657 .

27. Wynn v. United States, 397 F.2d 621, 625 \& n.23 (D.C. Cir. 1967). The suggestion in Wynn that in a criminal case the record should show whether the government had a chance to call the absent witness itself implies that the only time the adverse inference can be drawn against a defendant in a criminal case is when the defense refuses to disclose the name and whereabouts of a witness the government cannot locate. It narrows the meaning of "available to the defendant" as far as possible, greatly limiting the number of criminal cases in which the adverse inference can be invoked. In hight of the presumption of innocence, this restriction on the application of the rule and the resulting pressure on the government to rely on its own efforts to produce affirmative evidence seem proper. But to permit the inference to operate in criminal trials even this narrowly raises fifth amendment objections, as will be discussed in Part III of this Comment infra. 
inquiry on the record as to whether it could reasonably be inferred that the missing witness has superior knowledge of the facts, and discussed an appropriate procedure for making such a record. ${ }^{28}$ The court expressed concern for the "surprise" element inherent in the present administration of the rule-at the close of all the evidence a party might be penalized for not calling witnesses whose absence he could have satisfactorily explained to the court earlier, lad he known the inference would be invoked. The court suggested that a party seeking to obtain a charge on the inference so advise the trial judge and counsel at the close of his opponent's case. The requesting party would designate the names or classes of available persons not called and the reasons for concluding that they possess material knowledge of the facts. The party accused of nonproduction could then deinonstrate to the court the reasons for the failure to call, ${ }^{29}$ making a clear record for decision and review.

The motivation behind requiring such a record is laudable, but the drain on court time would be great. In very few cases would the evidentiary value of the inference, which could only strengthen or weaken other affirmative proof, justify the necessary expenditure of judicial time.

Even apart from problems regarding an adequate record, the imference rule is very difficult to administer fairly. Comment can easily be misleading, and only shight differences in wording or emphasis on the part of the judge or counsel may make the difference between proper and improper comment. In Wynn v. United States, ${ }^{30}$ for example, a defendant testified that he innocently spent his time with $X, Y$ and $Z$ on the day of the crime, but he produced none of these people as witnesses. At the actual moment of the crime, however, the defendant claimed to have been only with $X$, who was thus the only witness whose absence could properly give rise to an adverse inference. The prosecutor emphasized equally the failure to call $X, Y$ and $Z$, and the court broadly charged the jury that it might infer that the testimony of a witness available but not called would have been unfavorable. The comment by counsel and the court's instruction were held improper, as both might have misled the jury into drawing unwarranted inferences from the failure to call $Y$ and $Z .^{31}$ Such errors are easy to make, and counsel are not above deliberately making them on the chance that they might not be challenged or later reversed..$^{32}$

28. State v. Clawans, 38 N.J. 162, 172, 183 A.2d 77, 82 (1962).

29. Id.

30. 397 F.2d 621 (D.C. Cir. 1967).

31. Id. at 625-26.

32. See, e.g., Newell v. Slayton, 468 F.2d 888 (4th Cir. 1972). In Newell, a prosecution for rape, the defendant produced only one character witness and asserted 
While tighter control over the operation of the inference rule is necessary, McCormick advises against "spinning a web of rules" around the proper scope of argument. In his view, the proper remedy for fallacious argument is "the answering argument and the jury's good sense." B3 But there are difficulties with this approach. The reasons for nonproduction of the evidence, such as fear of impeachment, may not be information one would wish to lay before a jury. And, the damage caused by prejudicial argument cannot be completely repaired: instruction may not erase all adverse effect, and even a jury with "good sense" might be swayed by a fallacious argument persuasively dehivered. As the Supreme Court has recognized, ${ }^{34}$ there is a difference between what the jury might infer on its own, which can never be completely controlled, and what the jury might think when the absence of certain evidence is highlighted by counsel's comment or the judge's instructions.

\section{II}

\section{THE INFERENCE RULE AND THE DEMISE OF Griffin}

Griffin v. California ${ }^{35}$ erected a constitutional barrier around a criminal defendant's silence, protecting it from inference and comment by the prosecutor and the court. ${ }^{36}$ Courts have not, however, extended the fifth amendment to bar comment on a defendant's failure to produce material testimony other than his own. ${ }^{37}$ In theory, the distinction is clear, but as a practical matter it is very difficult to administer, and the result is an abuse of the privilege against self-mcrimina-

that his defense was consent, that the victim was not believable. The prosecutor in his summation attributed to the defendant an alibi defense, commented that defendant had produced no alibi witnesses, and sought to raise an adverse inference from the "omission." The appellate court recognized the "red herring of an alibi defense" and chastized the prosecutor for his "overzealous tactic." Nonetheless, the conviction was upheld.

33. MCCORMICK $\$ 272$, at 659 .

34. What the jury may infer, given no help from the court is one thing.

What it may infer when the court solemnizes the silence of the accused into evidence against him is another.

Griffin v. California, 380 U.S. 609,614 (1965).

35. 380 U.S. 609 (1965).

36. Griffin lield unconstitutional Article I, section 13 of the California Constitution, which permitted comment by the court and counsel on a defendant's failure to explain or deny the evidence produced against him. The federal courts already had a long established no-comment rule based on Congressional statute [See Wilson v. United States, 149 U.S. 60 (1893) (forbidding comment on the basis of the Act of Mar. 16, 1878, cl. 37, 20 Stat. 30, now 18 U.S.C. \& 3481 (1971)], and all but six states had some form of no-comment rule. But Griffin for the first time established the no-comment rule as a constitutional imperative.

37. See, e.g., Kitchell v. Umited States, 354 F.2d 715, 718-19 (1st Cir. 1966), cert. denied, 384 U.S. 1011 (1966); United States v. Lyon, 397 F.2d 505, 509 (7th Cir. 1968), cert. denied sub nom. Lysczyk v. United States, 393 U.S. 846 (1968). 
tion. Frequently, for example, a prosecutor will comment on a lack of defense evidence in broad, sweeping terms such as, "the state's evidence stands umimpeached and uncontradicted," or, "we have heard no testimony to the contrary."38 Such remarks may be permissible under the inference rule, but, depending on the particular facts of the case, or even on the speaker's tone, inflection, or gesture, they may improperly and unconstitutionally call attention to the defendant's own failure to testify.

When a comment by the prosecution is objected to as improper, the court gauges its constitutionality by determining whether the language was "manifestly intended to be, or if it was of such character that the jury would naturally and necessarily take it to be [,] a comment on the failure of the accused to testify."38 While this "naturally and necessarily" rule is supposed to protect against unwarranted comment, the protection may be illusory. A defendant must object to an ambiguous remark when made or lose his right to raise the issue on appeal..$^{40}$ The underlying assumption is that any prejudice will be avoided by prompt instruction - even though the instruction itself calls attention to the defendant's silence, the very evil to be avoided under Griffin.11 Furthermore, when a remark is found on appeal to violate constitutional standards, the harmless error rule applies. ${ }^{42}$ But more importantly, courts have so narrowly interpreted the "naturally and necessarily" test that few remarks not directly naming the defendant are found to contravene the fifth amendment exception to the inference rule. Comment has been held improper only if it is clear that the defendant is the only person who could have presented

38. See cases collected in Annot., 14 A.L.R.3d 723 (1967).

39. Morrison v. United States, 6 F.2d 809, 811 (8th Cir. 1925). This test was developed prior to Griffin under the federal statutory no-comment rule, but remains the same today.

40. United States v. Nasta, 398 F.2d 283, 285 (2d Cir. 1968).

41. While a defendant, if he so requests, has a right to an instruction that his failure to testify creates no presumption of guilt [Bruuo v. United States, 308 U.S. 287, 292-93 (1939)], the cases are split as to the propriety under Griffin of an unrequested instruction that the failure to testify raises no adverse inferences, for the instruction itself calls attention to the defendant's silence, see cases collected in Annot., 18 A.L.R.3d 1335 (1968).

42. Chapman v. California, 386 U.S. 18 (1967). For a discussion of the difficulty in applying this standard, see Note, Constitutional Law-Comment on Defendant's Failure to Testify: Harmless Error, 19 CASE W. Res. L. Rev. 757 (1968). The author criticizes the California courts for finding improper comment harmless beyond a reasonable doubt merely by examining the record for other "overwhelming evidence" rather than by analyzing the nature and extent of the comment in relation to the verdict obtained. The author suggests that the only workable solution is a "return to the position that constitutional error can never be disregarded as harmless." Id. at 765. See also Lewis, The High Court: Final . . But Fallible, 19 CASE W. Res. L. Rev. 528, 586-89 (1968). 
the relevant evidence. ${ }^{43}$ An ambiguous remark is proper as "mere" comment on the failure to produce a knowledgeable witness if there is any person other than the defendant who might have testified on that particular issue. But certainly if there is only one other uncalled witness-or even if there are several-the jury will understand the ambiguous remark as a reference in part to the defendant's own silence. ${ }^{44}$

The extent to which courts have gone to justify ambiguous remarks about the lack of defense evidence and to minimize the effect of the Griffin exception to the general inference rule is demonstrated by United States ex rel. Leak v. Follette. ${ }^{45}$ In ruling on the propriety of the prosecutor's repeated references to uncontradicted evidence, the court surveyed federal decisions both before and after Griffin and remarked on their "resourcefulness" in finding persons other than the defendant who could have contradicted the prosecution's evidence. ${ }^{46}$ It held the disputed remarks on the record before it to be proper

43. Compare the facts on which comment was permitted in United States v. Cox, 428 F.2d 683 (7th Cir. 1970), cert. denied, 400 U.S. 881 (1970), and United States ex rel. Leak v. Follette, 418 F.2d 1266 (2d Cir. 1969), cert. denied, 397 U.S. 1050 (1969), with the facts on which comment was deemed improper in RodriguezBandoval v. United States, 409 F.2d 529 (1st Cir. 1969); United States v. Poole, 379 F.2d 645 (7th Cir. 1967); Desmond v. United States, 345 F.2d 225 (1st Cir. 1965); and Linden v. United States, 296 F. 104 (3d Cir. 1924).

44. Factors found relevant to the "naturally and necessarily" determination include: whether the statement is more readily understood as a broad reference to the evidence adduced by the state rather than to the defendant's failure to testify [United States v. Lyon, 397 F.2d 505, 509 (7th Cir. 1968), cert. denied sub nom. Lysczyk v. United States, 393 U.S. 846 (1968); United States ex rel. Leak v. Follette, 418 F.2d 1266, 1268 (2d Cir. 1969), cert. denied, 397 U.S. 1050 (1970)]; whether there is any direct reference to the defendant, [Leak v. Follette, 418 F.2d at 1268]; whether the prosecutor repeated the remark [Jacobs v. United States, 395 F.2d 469, 477 (8th Cir. 1968)]; whether the defense failed to produce any evidence at all, nuaking the remark just an obvious statement of the truth [Id. at 477; Davis v. United States, 297 F.2d 126, 127 (4th Cir. 1968)]; and whether the statement referred only to the prosecution's evidence establishing the corpus delicti [Ruiz v. United States, 365 F.2d 103, 105 (10th Cir. 1966)]. Obviously, however, the test is very subjective; while these various factors help justify a conclusion, a judge can only guess at what effect such comments have on the jury.

45. 418 F.2d 1266 (2d Cir. 1969), cert. denied, 397 U.S. 1050 (1970).

46. Id. at 1269. The court took special note of Hood v. United States, 59 F.2d 153, 155 (10th Cir. 1932), in which the prosecutor noted testimony that a witness had bought home-brew of the defendant and added, "Who says he didn't do it? Who denies-?" The remarks were held proper since a third party might have been present, though no such party was suggested by the record. An earlier example of such "resourcefulness" to avoid reversal for improper comment is Robiho v. United States, 291 F. 975, 985 (6th Cir. 1923), in which the district attorney commented, "Mrs. Taylor says she had these conversations with [the defendant], and no one conies before this jury to deny them." Many of the disputed conversations were had on the telephone, but the court stated that since the record did not indicate what conversations the comment referred to, it did not necessarily appear that sone third party was not present, and the comment was not improper. 
because the possibility of contradiction through alibi witnesses existed, even though the defendant apparently made no alibi argument. ${ }^{47}$ Apparently the court reasoned that inroads on the "naturally and necessarily" test had already stretched the limits of permissible comment so $\mathrm{far}^{48}$ that it could permit ambiguous remarks whenever they might not be understood to refer directly to the defendant-even if that meant attributing to him an alibi defense he had never raised. Under this reasoning, the test for constitutionality in effect becomes not whether the jury would naturally and necessarily understand the remarks to refer to the defendant, but whether the record precludes the existence of an unknown, uncalled party whom the defendant might have put on the stand and to whom the ambiguous comments might refer.

This reasoning demonstrates flagrant disregard for the spirit of Griffin. If the record gives no indication of the existence of a party who might have been called as a witness, it is a mockery to pretend that general remarks about uncontradicted evidence will direct the jury's attention anywhere other than to the nontestifying defendant. ${ }^{49}$ Furthermore, such remarks suggesting inferences based on nothing more than speculation are not even justifiable under the inference rule itself. A defendant's conduct in not producing evidence has evidentiary significance only when a witness with knowledge of material facts

47. 418 F.2d at 1270 .

48. The court mentions two inroads upon the test: first, the requirement of immediate objection and request for a curative instruction; and second, the "fair rejoinder" principle which permits the prosecution to reply to a defense attack on the credibility of a government witness by "making statements which would otherwise be improper." Id. at 1269-70.

49. A few cases have rejected the "resourceful" approach and have emphasized that the record must affirmatively suggest the existence of an uncalled witness before general, ambiguous remarks about uncontradicted evidence pass the test of constitutionality. See Rodriguez-Bandoval v. United States, 409 F.2d 529, 531 (1st Cir. 1969); Desmond v. United States, 345 F.2d 225, 227 (1st Cir. 1965); and Commonwealth v. Domanski, 332 Mass. 66, 70, 123 N.E.2d 368, 371 (1954). Other courts have hkewise advised caution in treading too near the Griffin zone of privileged silence. See, e.g., Kitchell v. United States, 354 F.2d 715 (1st Cir. 1966), cert. denied, 384 U.S. 1011 (1966):

Though not obviously a comment upon the defendants' failure to take the stand, ... as distinguished from comment upon the absence of other witnesses who might have been called to offer contradiction, ... we think such remarks are generally undesirable because the jury is likely to understand them in the former sense.

Id. at 718-19. See also State v. Dent, 51 N.J. 428, 241 A.2d 833 (1968):

Remarks which skirt the edges of impermissible comment are neither desirable nor worth the risk of reversal .... Caution is desirable until the constitutional boundaries of permissible comment on the state of the evidence when the accused does not testify are thoroughly established. In the meantime the sensible course is to assume that jurors can see as well as hear, and do not have to be told when evidence is uncontradicted.

Id. at $441,241 \mathrm{~A} .2 \mathrm{~d}$ at 841 . 
does exist. Even then, the requirement of peculiar availability must still be met before any inference arises; and in inference cases generally courts are demanding greater, rather than less, clarity in the record. The reasoning underlying Leak $v$. Follette and similar holdings is unacceptable, and its consequence is an abuse of the defendants' fifth amendment privilege.

This abuse would be partly alleviated if judges would restrict remarks on the failure to produce witnesses to those clearly justified under the traditional inference rule. Comment would then be limited to remarks about specific uncalled witnesses whose existence and probable knowledge of material facts are verifiable from the record..$^{50}$ This limitation would eliminate remarks that seriously threaten the defendant's privilege against self-incrimination as defined by Griffin, and it would force both trial and appellate judges to focus more clearly on the validity of the particular inference being raised. ${ }^{51}$ Strict application of the inference rule would not, lowever, cure the shortcomings of the rule itself. Even specific comments about a defendant's failure to produce a witness are likely to spark jury speculation about why the defense is apparently withholding evidence, and ultimately, why the defendant did not himself testify. ${ }^{52} \mathrm{~A}$ preferable solution is to extend the privilege against self-incrimination to bar all remarks about a defendant's failure to produce witnesses, regardless of whether the missing witness is the defendant himself or another.

\section{III}

\section{EXPANDING THE NO-COMMENT RULE}

\section{A. The Scope of Fifth Amendment No-Comment}

The scope of the fifth amendinent privilege against self-incrimination was defined in Schmerber v. California, ${ }^{53}$ the Court holding that

50. See text at notes 27-29 supra, for a discussion of what the record should show affirmatively before comment on the failure to call a witness is proper. The strict record requirements suggested would improve the reliability of the inference in any case, but should be mandatory in criminal cases because of the high need for accurate fact-finding.

51. Narrowing the permissible breadth of comments on the failure to produce a knowledgeable witness would also protect the presumption of innocence. Even if a defendant has witnesses that might be called, he has the right to send the case to the jury without doing so trusting solely in the weakness of the government's case. Broad comments about the failure to produce evidence strongly suggest that the defendant does have a duty to attempt to prove his innocence, and, even though the jury is instructed to the contrary, such plainly erroneous suggestions are wisely avoided. See United States v. Lombardozzi, 335 F.2d 414, 417 (2d Cir. 1964), cert. denied, 379 U.S. 914 (1964).

52. Sce United States v. Poole, 379 F.2d 645, 649 (7th Cir. 1969).

53. 383 U.S. 757 (1966) (the results of a compelled blood-alcohol test are "real 
the privilege protects an accused from being compelled to "provide the State with evidence of a testimonial or communicative nature."54 In Griffin, the Court reasoned that forcing a defendant to choose between taking the stand against his wishes or remaining silent and suffering an adverse inference is a way of compelling him to testify against himself. Adverse comment on a defendant's failure to testify is thus a penalty for asserting a constitutional privilege. ${ }^{55}$ The language in Schmerber and the Court's reasoning in Griffin suggest that any application of the inference rule in criminal cases violates the fifth amendment.

The no-comment rule must be extended to a defendant's failure to produce a material witness other than himself if permitting comment on the defendant's conduct amounts to compelling the defendant to provide the state with evidence of a testimonial or communicative nature. There are three components to this inquiry: (1) whether the conduct and comment are technically evidence, (2) whether the possibility of comment creates an element of compulsion, and (3) whether the conduct and comment are evidence of a testimonial or communicative nature.

The defendant's conduct and comment thereon can validly be characterized as "evidence." With respect to the failure of the defendant to testify in Griffin, the Court found that "the prosecutor's comment and the court's acquiescence are the equivalent of an offer of evidence and its acceptance." 56 In this regard, comment on a defendant's refusal to testify is indistinguishable from comment on his failure to produce other witnesses. Although there is no formal offer of proof, the effect of the inference rule is to permit the state to tender to the jury for its consideration the failure of the accused to present material evidence. While the inference raised by the defendant's conduct cannot supply any missing eleinent of proof of guilt, it can strengthen the prosecutor's case and facilitate a conviction..$^{57}$

The compulsion element is also present. A defendant is forced to choose between calling a witness he would rather not produce or

or physical evidence" and therefore not within the scope of the fifth amendment's protection).

54. Id. at 761 .

55. Griffin v. California, 380 U.S. 609, 614 (1965).

56. Id. at 613.

57. See note 21 supra.

The California constitutional provision declared unconstitutional in Griffin was earlier upheld against a fourteenth amendment due process challenge because the inference does not shift to the defendant the burden of proof or duty to go forward with the evidence. Adamson v. California, 332 U.S. 46, 58 (1947). This distinguishes the inference arising from a failure to call from statutorily created rebuttable presumptions which do shift the burden of going forward with the evidence to the defendant. 
suffering the penalty of unfavorable comment. ${ }^{58}$ This is a far cry from the "rack and screw," but even this mild form of compulsion is sufficient to invoke the protection of the fifth amendment.

It is not so obvious, however, that the compelled evidence is of a testimonial or communicative nature. In Malloy v. Hogan, ${ }^{00}$ the Supreme Court stated that the purpose of the fifth amendment is to ensure that the government proves charges against an accused "by evidence independently and freely secured," not by evidence coerced "out of his own mouth." 11 Subsequently, the Court explamed in Schmerber that the phrase "out of his own mouth" is not to be understood in its narrowest, hiteral sense. The Court specifically disclaimed Wigmore's anatomical limitation of the privilege as preventing only "the employment of legal process to extract from the person's own lips an admission of guilt. ..." "02 Rather, the Court concluded, the privilege "reaches an accused's communications, whatever form they might take." 03 Clearly not only words, but also some conduct falls within the fifth amendment's protection: a head-shake ${ }^{04}$ or maintaining silence ${ }^{05}$ may be a protected testimonial or communicative act. As the following discussion will demonstrate, the failure of a criminal defendant to call witnesses also is such protected conduct.

Schmerber contrasts "testimomial or communicative" evidence with "real or physical evidence" taken fronı a defendant's own body. The fifth amendment does not prohibit compelling a person to "submit to fingerprinting, . . . to write or speak for identification, to appear in court, to stand, to assume a stance, to walk, or to make a particular gesture." ${ }^{\circ 6}$ Thus, the defendant may be compelled to exhibit his physi-

58. For a discussion of reasons unrelated to guilt why a party might not want to call a particular witness, see text accompanying notes 23-25 supra. A defendant's reasons for not calling witnesses and thereby prolonging his trial may seem even more compelling to him after he has heard the prosecutor's case and adjudged it to be weak. His choice to submit the case to the trier of fact without presenting evidence, but trusting rather in the prosecutor's failure to meet his high burden of proof, might indeed be the wisest tactical decision in the circumstances. Cf. Jones v. Superior Court, 58 Cal. 2d 56 (1962): “... [C]ompelled revelation by the defendant that he may have only a weak defense may itself be self-incriminating." Id. at 66 (Peters, J., dissenting) (fifth amendment values warrant protection of criminal defendant's case from discovery).

59. See note 55 and accompanying text supra.

60. 378 U.S. 1 (1964).

61. Id. at 8 .

62. 384 U.S. at 763 n.7, quoting 8 J. WIGMORE, EVIDENCE $\$ 2263$ (McNaughton rev. 1961).

63. 384 U.S. at 763-64.

64. Id. at 761 n.5.

65. Miranda v. Arizona, 384 U.S. 436 (1966). See note 23 supra.

66. 383 U.S. at 764 (footnote omitted). The cases are collected in $8 \mathrm{~J}$. Wromore, EVIDẸNCE $\$ 2265$ (McNaughton rẹv, 1961). 
cal characteristics and even actively to participate in producing evidence. Obviously, the distinction between testimonial and physical evidence is not a matter of active versus passive behavior. The key rather is to be found in Schmerber's statement that "petitioner's testimonial capacities were in no way implicated." ${ }^{27}$ Testimonial capacity is not synonymous with capacity for oral communication. Speech itself may only be physical evidence when used not for communication but for voice identification; ${ }^{88}$ conversely, communication through gestures utilizes testimonial capacity even though speech in a narrow sense is not involved. Therefore, "testimonial capacity" must signify a person's "higher faculties"-the ability to perceive, to understand, to remember and to communicate knowledge. The crucial distinction is between "compulsion of the accused to exhibit his physical characteristics . . . and compulsion to disclose any knowledge he might have.""9

The application of this distinction is evident in California $v$. Byers. ${ }^{70}$ The Court, in a plurality opinion, upheld a California "hitand-run" statute requiring that a driver involved in an accident causing property damage stop immediately and identify himself. Five Justices, however, found that the stop-and-identify provision does conrpel the driver to give evidence of a testimonial and potentially incriminating nature. ${ }^{71}$ The act of stopping, with consequent self-identification, is a "testimonial" act because it communicates knowledge that one is potentially responsible for the accident.

When the prosecution comments on the inference arising from a defendant's failure to produce evidence, the effect of comment is to imbue the defendant's conduct with testimonial significance. The defendant's behavior in not calling the witness is treated as an admission that he knows the missing testimony would be unfavorable-an assertion in court about his own state of mind. ${ }^{72}$ The prosecutor is permitted to characterize the defendant's conduct as an act having testimonial or communicative significance and to tender it as such to the jury. Extracting from the defendant's trial conduct a harmful communication which the defendant would never voluntarily verbalize

67. 384 U.S. at 765 (emphasis added).

68. United States v. Wade, 388 U.S. 218, 222-23 (1967).

69. Id. at 222 (emphasis added).

70. 402 U.S. 424 (1971).

71. Justice Harlan agreed with the dissenters that the act of stopping and identifying oneself is testimonial, but cast the decisive vote upholding the statute by balancing the public interest in ensuring financial responsibility for accidents and the need for self-reportmg against the relatively small encroachment on the privilege against selfincrimimation. Id. at 449-53 (Harlan, J., concurring). The plurality opinion is criticized for its evasive treatment of the fifth amendment issue in Meltzer, Privileges Against Self-Incrimination and the Hit-and-run Opinions, 1971 SUP. CT. REv. 1.

72. See note 6 supra. 
is indistinguishable from coinpeling him to make an incriminating statement: the defendant is, in effect, forced to give evidence against himself. While the evidence does not coine "out of his own mouth," it quite clearly is a product of the defendant's inferred personal knowledge.

\section{B. Fifth Amendment Policies: The State-Individual Balance}

An expansion of the scope of the no-comment rule must, of course, be consistent with the policies and values underlying the fifth amendment privilege. Yet these policies can only be stated in very broad terms, ${ }^{73}$ and the privilege is given its real meaning through its application in specific situations. The Court in Griffin declared comment on the refusal to testify to be "a remnant of the inquisitorial system of criminal justice. . . which the Fifth Amendinent outlaws."74 Further, in recognizing the value of the privilege as a protection for those who might prefer to remain silent and rely upon the presuinption of innocence, ${ }^{75}$ the Court expressed its concern for the "fair stateindividual balance" which Wigmore cites as the primary justification for maintaining and expanding the modern fifth anendment privilege. ${ }^{78}$ The problem is to apply this broad concept of fairness to the effects of the inference rule in the criminal context, reasoning from the nature of the interests involved and analogizing to other fifth amendment decisions.

Criminal prosecutions involve different state and individual interests than do civil trials; hence, the different burdens of proof. The traditional evidentiary rule which permits an inference of questionable

73. Murphy v. Waterfront Comm'n., 378 U.S. 52 (1964):

[The privilege against self-incrimination] reflects many of our fundamental values and most noble aspirations: our unwillingness to subject those suspected of crime to the cruel trilemma of self-accusation, perjury or contempt; our preference for an accusatorial rather than an inquisitorial system of criminal justice; our fear that self-imcriminating statements will be elicited by inhumane treatment and abuse; our sense of fair play which dictates "a fair state-individual balance by requiring the government to leave the imdividual alone until good cause is shown for disturbing him and by requiring the government in its contest with the individual to shoulder the entire load," 8 WIGMORE, EVIDENCE (McNaughton rev. 1961), 317; our respect for the inviolability of the human personality and of the right of each individual "to a private enclave where he may lead a private life," United States v. Grunewald, 233 F.2d 556, 581-82 (Frank, J., dissenting), rev'd 353 U.S. 391, 1 L.Ed. $2 \mathrm{~d} 931,77 \mathrm{~S}$. Ct. 963; our distrust of self-deprecatory statements; and our realization that the privilege, while sometimes "a shelter to the guilty," is often "a protection to the innocent," Quinn v. Umited States, 349 U.S. 155, 162, 99 Id. at 55 .

L.Ed. 964, 972, 75 S. Ct. 668, 51 A.L.R.2d 1157.

74. 380 U.S. at 614 (citation omitted). See Ratner, Consequences of Exercising the Privilege Against Self-Incrimination, 24 U. CrI. L. REv. 472, 484 (1957).

75. 380 U.S. at 613.

76. 8 WIGMORE $\$ 2251$, at 317 . 
factual validity based on a speculative assessment of what an absent witness might have testified is perhaps justifiable in the civil context, but in criminal cases it is inconsistent with the necessity for factual accuracy and the interests protected by the "fair state-individual balance." In civil trials, the state's sole function is to provide a neutral forum in which parties can peaceably settle disputes through their own efforts and at their own expense. The winner is decided by a preponderance of the evidence, a test which presupposes and encourages the production of relevant evidence by both sides. Penalizing a party for withholding material evidence by allowing an adverse inference based on his conduct furthers society's goal of reaching a fair and informed adjudication. Furthermore, since each party in civil litigation must rely on its own resources to gather evidence, neither has an automatic advantage: the potential benefits and burdens of the inference rule fall equally on all litigants. In this context, application of the inference rule, if carefully controlled, seems fair.

In criminal trials, however, the resources of the opposing parties are not equal, and the state's interest is very different than in civil litigation. Society has constructed a vast apparatus to investigate crime and prosecute lawbreakers: its resources vastly exceed those of the ordinary criminal defendant. The state is better able than the defendant both to obtain all evidence relevant to the case and to discover evidence not produced by the defendant which will equip it to invoke the inference rule in its favor. The potential effects of the rule do not therefore fall equally on both sides. Furthermore, in a criminal trial the state's interest is not merely in providing a forum where the best evidence wins, or in justifying its own indictments by "winning" its prosecutions. Criminal sanctions-imprisonment, fines, and a criminal record-are the most severe our society can impose. To keep the state froin wrongly imposing these sanctions and to give each defendant a "fighting chance" against the power of the state, each person is shielded by constitutional safeguards and clothed with a presumption of innocence. The entire burden of proof is on the state; its evidence must convince "beyond a reasonable doubt and to a moral certainty." The state's only legitimate interest is in maximizing the accuracy of the fact-finding process while respecting the constitutional rules limiting its power to obtain and present evidence against the defendant. Use of the traditional inference rule in criminal trials does not reflect a fair consideration of relative state and individual resources, nor does it further the state's interest in factual accuracy. And it comes perilously close to contravening the presumption of innocence by permitting the prosecution to utilize ambiguities about the defendant's failure to call a witness to draw an inference of doubtful validity in order to ease the state's burden of affirmative proof. 
Rather, in most cases, the prosecution could avoid risking the dilution of a constitutional protection and also could increase the accuracy of the fact-finding process by itself producing the witness. Prohibiting comment would cast a slight burden on the state, which would have to choose between verifying the existence of and calling the witness or ignoring his existence altogether. This practice would, however, eliminate the danger of inaccurate inferences, preserve the integrity of the present no-comment rule, and protect the accused's presumption of innocence by making the government truly "shoulder the entire load" of producing evidence. This balance would better protect the mdividual and serve society's broad interests in preserving the integrity of our system of criminal justice.

Expanding the scope of the fifth amendment no-comment rule would also be consistent with the application of the fifth amendment privilege in other contexts. The fifth amendment requires that the state forego the benefit of a defendant's testimony even at the cost of hindering the fact-finding process. It requires the exclusion of a signed confession as not freely and voluntarily given when the police use physical or psychological coercion to persuade the accused to speak. It also prevents pre-trial discovery by the prosecution, although limited discovery is available to the defendant. ${ }^{77}$ These examples suggest that an underlying purpose of the fifth amendment is the protection of the individual's abihity to put up a "good fight." While the defendant is given specific protections, the state is not permitted to mitigate its heavy burden of proof, for we value individual dignity and fear the misuse of the state's power. This civilized sense of fairness, and perhaps our sense of self-preservation, dictate that when an individual finds the full force of the state's prosecutorial system focused upon him, we guarantee him some measure of control over the proceedings that so drastically alter his life. A defendant may choose to testify, or he may choose not to. Permitting a defendant to choose what witnesses to call or not to call-without the penalty of comment-would likewise assure him some small measure of tactical choice and would be consistent with our fifth amendment values of fairness.

IV

Practical Consmerations in Expanding the No-Comment Rule The conclusion that a criminal defendant's failure to produce

77. Fed. R. CRIM. P. 16; Mr. Justice Douglas, dissenting in part to the promulgation of amendments to the Rules of Criminal Procedure, 383 U.S. 1087, 1090-92 (1966); Prudhomme v. Superior Court, 2 Cal. 3d 320, 466 P.2d 673, 85 Cal. Rptr. 129 (1970). 
a knowledgeable witness should be protected by the fifth amendment no-comment rule will surely raise protests that one realistically cannot expect a prosecuting attorney to watch his words so carefully as never to make a reference to the lack of defense evidence. And one's sense of dismay will probably bear a close relationship to personal doubts about the necessity and wisdom of the privilege against self-mcrimination in general.

But the inconvenience to the prosecution of having to guard against improper comment is certainly no justification for rejecting the no-comment constitutional safeguard when all the criteria for invoking fifth amendment protection are met. Under Griffin, prosecutors are already required carefully to measure their words and avoid statements that might draw attention to the accused's silence. Yet the endless verbal hair-splitting which inevitably results from trymg to distinguish such remarks from those nierely refering to a failure of evidence other than the defendant's testimony, only leads attorneys and courts alike to be careless with the defendant's privilege. The additional burden of caution that would result from an expansion of the no-comment rule would mean, in many cases, no more than that the prosecution would be forced to avoid the general, ambiguous remarks about lack of contradictory evidence which currently confuse the courts and erode the constitutional protection established by Griffin. The guiding rule should be that comment must be limited to a discussion of evidence actually presented by the state and the defendant, and all remarks about missing evidence must be avoided. This absolute rule might even be easier for an attorney to apply than one requiring him to diagnose the ambiguities of each item of withheld evidence. Furthernore, it should encourage more specific discussion of the relative weight of contradictory evidence, thereby aiding the trier of fact.

Finally, an accidental misstatement need not result in autoniatic reversal, as comments found on appeal to be improper and uncorrected are tested by the harmless error rule. At least in cases of inadvertent slips, error would most likely be harmless. But few cases would have to reach even this level of review. Trial judges, freed from the mire of evaluating each ambiguous remark against the "naturally and necessarily" test, would be able sufficiently to correct errors to avoid reversal by promptly instructing the jury that since the defendant has no burden of proof, he has no obligation to produce witnesses-and therefore no inference can arise from his decision not to do so. This is the least the fifth amendinent requires.

Julie E. McDonald 